\title{
Designing a performance appraisal system based on balanced scorecard for improving productivity: Case study in Semnan technology and science park
}

\author{
Mohammad Hemati $^{\mathrm{a}^{*}}$ and Majid Mardani ${ }^{\mathrm{b}}$
}

${ }^{a}$ Assistant professor, management Department, Islamic Azad University, Semnan Branch, Semnan, Iran

${ }^{b}$ M.A student, management Department, Islamic Azad University, Semnan Branch, Semnan, Iran

\begin{tabular}{l}
\hline A R T I C L E I N F O \\
\hline Article history: \\
Received December 25, 2011 \\
Received in Revised form \\
March, 25, 2012 \\
Accepted 24 April 2012 \\
Available online \\
May 1 2012 \\
\hline Keywords: \\
Strategy \\
Performance appraisal \\
Balanced Scorecard \\
Productivity \\
Technology and Science Parks \\
Semnan University
\end{tabular}

A B S T R A C T

\begin{abstract}
Today, organizations for holding and improving their competing merit use performance measurement for evaluation, control, supervision and improvement of their trading processes. Medium and small companies in technology and science parks are very useful in economic revivification and technology development. Technology and science parks have provided necessary consultations, information, suitable equipments, and services for developing technology unites and prepare them for independent presence in industry. One of the necessary elements for the success and improvement of performance in these companies is to establish and implement balanced scorecard, which can be used to reach desired goals, strategies and to improve performance. In this article, we use a structured method for calculating efficiency of four perspectives of balanced scorecard. Statistical society of this research was Semnan technology and Science Park and seven experts are selected for answering questions of the survey. We also complete questionnaire and determine index and relative importance of all indices. For developing strategic goals of Semnan technology and science park according to four perspectives of balanced score card (finance, growth and learning, internal process), six meetings were hold and finally all crisis macro goals index were identified and they were analyzed for evaluating performance.
\end{abstract}

\section{Introduction}

These days, we see different reports on the average number of years people live in the world and realize the average life expectation is somewhere between 60 to 80 years but the average life cycle of in industry in many European and North American enterprises are only limited to 12.5 years. The primary objective of many science park organizations is to increase the average life cycle as much as possible. This is a fact that many small and medium scale businesses (SMEs) are the basis of economic growth in developing countries and science park units could significantly contribute to the growth of such organizations.

* Corresponding author. Tel:+98- 9125326924

E-mail addresses: mo928hem@yahoo.com (M. Hemati) 
Performance measurement is one of the most important management techniques to see how effective management team performs his/her duties. There are literally different methods for measuring the relative performance of a particular firm and many of them rely on financial figures. However, there are always some non-financial indices, which are more important than financial data. Although traditional performance measurement relies solely on financial figures but Kaplan and Norton (1992) explained that intangible assets are the most important part of an organization. These days, we witness that a small group of people build a business unit with virtually small amount of investment and in less than a few years; the business model is sold billions of dollar. An example of this event is a one billion dollar take-over bid that facebook offered for a small firm who were operating with 13 people in 2012.

Therefore, we can conclude that performance traditional measurements established based on management accountancy system is not reliable (Koskela \& Stenbacka, 2009; Dobisi, 2011).

Because of these limitations, characteristic of non-financial performance measurement has been emerged in this field. Basically, these properties are associated with organizational strategy and they have emerged to non-financial measurement. Therefore, multi-dimensional and uniform performance management systems have been extended, which could divide them to two separate groups (Wongrasem \& Simmons, 2003; Wu et al., 2009; Khan et al., 2011).

1) The first group is associated with evaluation techniques. Examples of these kinds of techniques include Deming Award in Japan, Malkom Baldrig in U.S.A, European Award for Quality Award or EFQM, etc.

2) Performance measurement based on comprehensive factors associated with financial and nonfinancial figures. Examples of these techniques include data envelopment analysis (DEA), balanced score card (BSC), etc. So, one of problems that necessitate research is manner of recognition, prioritizing of model variable.

In this article, we consider a method for modeling of performance evaluation system based on balanced scorecard for improving performance of Semnan science and Technology Park.

\section{Research conceptual framework}

Kaplan and Norton (1992) are believed to be the first who in traduced the idea of BSC. They introduced their results with the name of performance measurements in future organization (that has been done in 1990) as BSC. They believed that BSC is capable of translating strategic goals and organization mission into a group of performance measurement. In addition, these two researchers improved BSC to prepare strategies and to increase in organization and control management with three articles in 1993, 1994 and 1996 office of growing centers of science ministry, researches and technology (Kaplan \& Norton, 1996). The primary objective of BSC is to provide a comprehensive perception on organization financial and non-financial figures, which would help them implement organization strategies. The results of this article is to investigate the relationship between financial and non-financial items (Huang, 2009). BSC was a measurement system that place financial index by non-financial index. Four measurement perspectives in this method include (Kaplan \& Norton 1992; Ashley et al., 2008; Tohidi et al., 2010, Wu et al., 2011):

\section{A: Financial B: Customers C: Internal process $\quad$ D: Learning and growth}

In 1996, BSC has been emerged to measurement instrument and indices have been associated with each other using cause and effect relationships. So financial indices were final output, which show financial results and lead to growth and promotion of organization in long term. Therefore, for promotion financial performance of organization, there are two solutions:

\section{1: Income growth 2: Productivity improvement}

To setup a long term strategy, we need to look for long term objectives while we measure the shortterm goals in terms of productivity (Kloot \& Martin, 2008) and Kaplan and Norton consider the following classification for intangible assets, 
1: Human capital 2: Informational capital 3: Organizational capital (Kaplan \& Norton, 2000).

Today, BSC has been specified as a strategic management and learning system, which is based on company general goals. BSC pays attention to create values in long term and the primary objective of BSC is to shape strategy (Kaplan \& Norton, 2005).

\section{Methodology}

\subsection{Research goals}

- Designing and evaluating performance of Semnan University Technology and Science based on BSC,

- Specifying and evaluating essential goals related to park's strategies and determining indices for each goal,

- Considering measure of effect of variables of BSC on performance of Semnan University Technology and Science Park,

- Continues improvement of Semnan University Technology and Science Park by redirecting the necessary feedbacks to park performance layers.

\subsection{Research questions}

- What is the effect of weights of four perspectives on performance of Semnan University Technology and Science Park?

- What are essential goals related to park strategies and what is index of each goal?

- What is the evaluating performance of Semnan University Technology and Science Park based on BSC model?

\subsection{Research variables}

Different methods have been provided for implementing and modeling BSC and the proposed model of this paper uses "Niyon" method, which is based on activity for implementing and modeling BSC in Semnan University Technology and Science Park. Niyon (2002) divides stages of implementation of BSC into the following three phases as follows,

$$
\text { 1: planning phase } \quad 2 \text { : developing phase } 3 \text { : performing and establishing phase }
$$

\subsection{Research statistical Population}

Statistical population of this research include experts, managers and experts of Semnan University Technology and Science Park in different unites. Because, method of collecting data in this research is survey, so the data has been collected by holding meetings with park's managers and staffs.

\subsection{Research executing stages}

Stages of implementing BSC can be divided to three total steps:

\section{First step: planning stage}

Stages of this step include:

\section{1: Developing goals for BSC}

When starting, the biggest principles, which create difficulty in this project, are deleted.

\section{2: Determining organizational unit for BSC}

In this stage all unites of Semnan University Technology and Science Park have been determined and specified for establishing and implementing.

3: Getting executive supporter:

Executive supporter of this project is Semnan University Technology and Science Park. 
4: Building balanced score card team.

This team includes park's chief, public relations responsibility, support manager, responsible of office of relation to industry, etc.

\section{5: Preparing project program}

Semnan university technology and Science Park for implementing BSC could prepare a plane of development (strategic goal map) for implementing this project.

6: Developing a plane of establishing relation

BSC project needs participation of all staff and is first condition for participating park's people, establishing relation and intercourse with them about BSC.

\section{Second step: development step}

Stages of this step include:

1: Collecting and distributing required materials

Preparing forms of collecting information and BSC for measuring each of respects have been done in this stage.

2: Development with endorsing on commission, respective and strategy

In this stage commission, respective, goals, duties and preparing park's performance aspects of different unites have been considered and analyzed.

3: Interviewing with park's top managers

Making cultural, educational aspects of BSC model and stages of performing BSC have been performed in this stage.

4: Developing strategic goals in each of aspect of BSC

Achieving and grouping them in balanced scorecard aspects have been done in this stage.

5: Selecting performance measurement for strategic goals

In this stage, vital goals and their indices for evaluating and measuring performance have been considered and analyzed.

\section{Third step: establishment and executing step}

Stages of this step include:

1:Determining proportional value of BSC using analyzes data hierarchy

Determining relation among goals, criteria, indices and programs for park's process, unites; staff for determining proportional values of BSC are executed in this stage.

2: Calculating efficiency and achieving to goals of indices in different domains

In this stage, efficiency of each goals and indices has been calculated.

\section{3: Calculating efficiency of park}

This stage is last stage from implementing steps of balanced scorecard. In this stage, efficiency of park total has been calculated. In Fig. 1 algorithm and flowchart of executive stages have been provided.

Also output these meetings and their stages have been provided in Table 1 and Fig 2. 


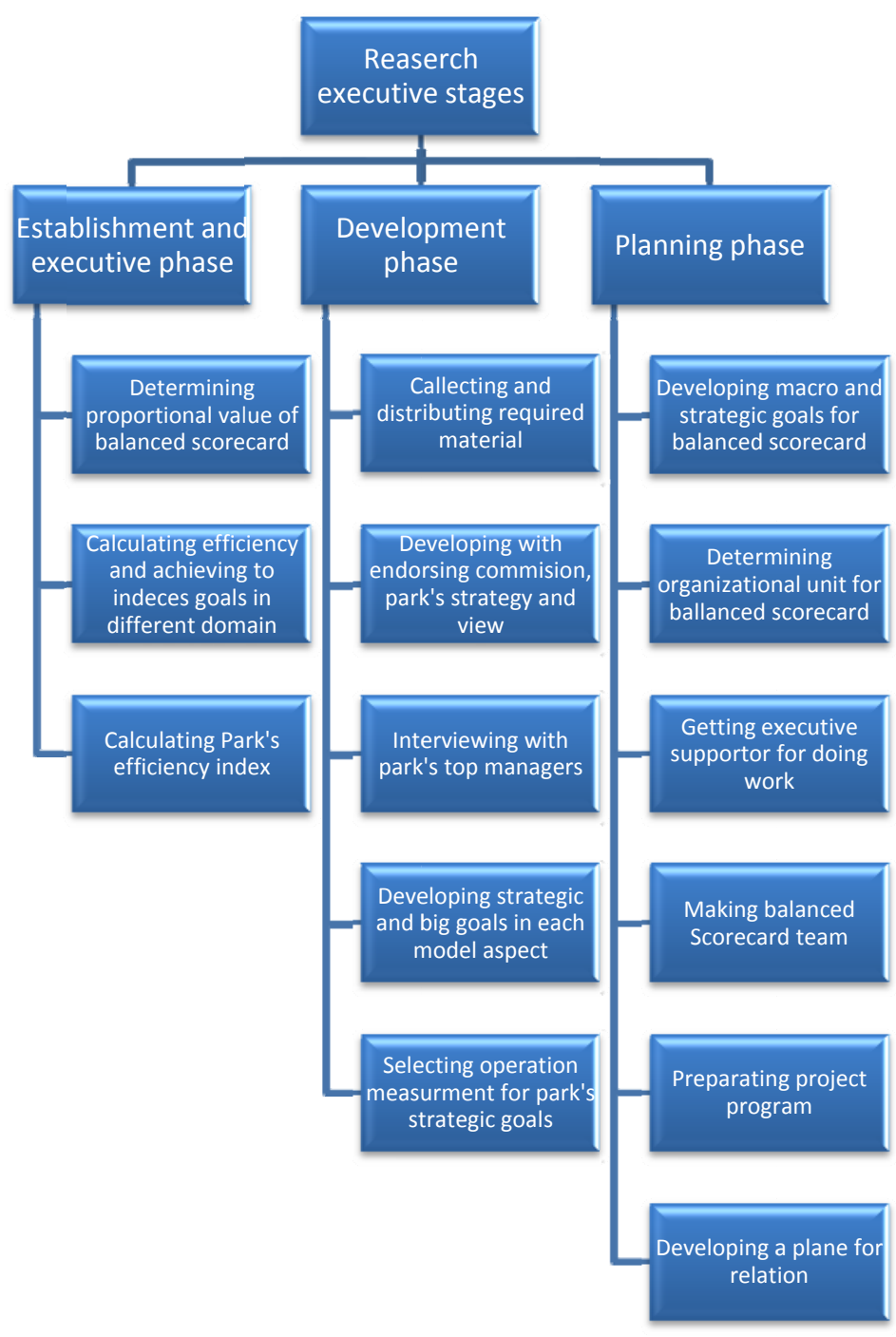

Fig. 1. Research stages executive algorithm.

\section{Table 1}

Macro goals in balanced scorecard in Semnan Technology and Science Park

\begin{tabular}{|c|c|c|c|}
\hline Row & BSC Perspective & Crisis macro goals & Support assistance \\
\hline 1 & $\begin{array}{l}\text { Financial } \\
\text { Perspective }\end{array}$ & $\begin{array}{l}\text { Make trading ideas and application university survey } \\
\text { results }\end{array}$ & $\begin{array}{l}\text { Support assistance / } \\
\text { technology assistance }\end{array}$ \\
\hline \multirow{2}{*}{2} & \multirow{2}{*}{$\begin{array}{l}\text { Learning and } \\
\text { growth } \\
\text { Perspective }\end{array}$} & $\begin{array}{l}\text { Completing active and dynamic cycle for developing } \\
\text { initiative }\end{array}$ & \multirow[t]{2}{*}{ technology assistance } \\
\hline & & $\begin{array}{l}\text { Helping to increasing wealth in society by developing } \\
\text { knowledge centered economic }\end{array}$ & \\
\hline 3 & $\begin{array}{l}\text { Customer } \\
\text { Perspective }\end{array}$ & $\begin{array}{l}\text { Using public and university equipment for supporting, and } \\
\text { extending technology in society }\end{array}$ & Support assistance \\
\hline 4 & $\begin{array}{l}\text { Internal process } \\
\text { Perspective }\end{array}$ & $\begin{array}{l}\text { Supporting creation and extension of technology small and } \\
\text { medium firms and supporting research firms with } \\
\text { technology developing and employment goal }\end{array}$ & $\begin{array}{l}\text { technology assistance / } \\
\text { Support assistance }\end{array}$ \\
\hline
\end{tabular}




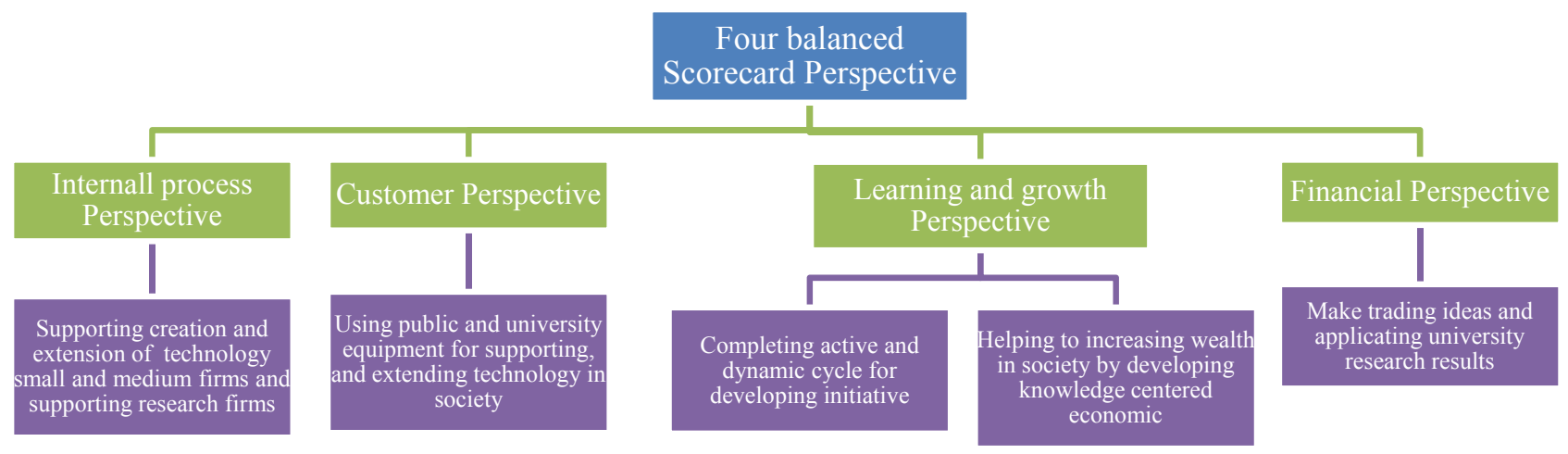

Fig. 2. Macro goals in balanced scorecard perspective in Semnan Technology and Science Park

\section{Data Analyses}

In this section, we present details of the implementation of the proposed. We also explain details of our findings on essential macro goals for the proposed model.

\subsection{Selecting performance indices for park's essential macro goals}

In this stage, all indices related to each strategic goal have been collected and among them, the most suitable index has been selected. In Table 2, abstract of essential macro goal and indices are presented.

\section{Table 2}

Essential macro goals and determined performance measurement in Semnan University Technology and Science Park

\begin{tabular}{|c|c|c|c|c|}
\hline \multicolumn{2}{|c|}{ BSC Perspective } & \multirow{4}{*}{$\begin{array}{l}\text { Essential macro goals } \\
\text { Make trading ideas and application } \\
\text { university research results }\end{array}$} & \multirow{2}{*}{$\begin{array}{l}\text { Performance measurement } \\
\text { Percent rate of financial support from fixed } \\
\text { planes }\end{array}$} & \multirow{2}{*}{$\begin{array}{l}\text { Organizational unit } \\
\text { Support assistance / } \\
\text { Financial unit }\end{array}$} \\
\hline & & & & \\
\hline \multirow[t]{2}{*}{1} & \multirow[t]{2}{*}{$\begin{array}{l}\text { Financial } \\
\text { Perspective }\end{array}$} & & $\begin{array}{l}\text { Rate of spend budget in along improving } \\
\text { and extending park }\end{array}$ & $\begin{array}{l}\text { Support assistance / } \\
\text { Financial unit }\end{array}$ \\
\hline & & & Rate of spend budget in doing research & $\begin{array}{l}\text { Support assistance / } \\
\text { Financial unit }\end{array}$ \\
\hline \multirow{5}{*}{2} & \multirow{5}{*}{$\begin{array}{l}\text { Learning } \\
\text { and growth } \\
\text { Perspective }\end{array}$} & \multirow{4}{*}{$\begin{array}{l}\text { Completing active and dynamic } \\
\text { cycle for developing initiative }\end{array}$} & $\begin{array}{l}\text { Efficiency rate of park's supporting from } \\
\text { technology units }\end{array}$ & $\begin{array}{l}\text { Technology assistance / } \\
\text { Research unit }\end{array}$ \\
\hline & & & Number of technology unit to develop & $\begin{array}{l}\text { Technology assistance / } \\
\text { Developed center unit }\end{array}$ \\
\hline & & & $\begin{array}{l}\text { Percent of growth of technology units from } \\
\text { scientist environment }\end{array}$ & $\begin{array}{l}\text { Technology assistance / } \\
\text { Developed center unit }\end{array}$ \\
\hline & & & Hold educational hours for technology units & $\begin{array}{l}\text { Support assistance / } \\
\text { Human resource unit }\end{array}$ \\
\hline & & $\begin{array}{l}\text { Helping to increasing wealth in } \\
\text { society by developing knowledge } \\
\text { centered economic }\end{array}$ & Number of provided ideas in market & $\begin{array}{l}\text { Technology assistance / } \\
\text { Intellectual property unit }\end{array}$ \\
\hline \multirow{4}{*}{3} & \multirow{4}{*}{$\begin{array}{l}\text { Customer } \\
\text { Perspective }\end{array}$} & \multirow{4}{*}{$\begin{array}{l}\text { Using public and university } \\
\text { equipment for services, supporting, } \\
\text { initiative and extending technology } \\
\text { in society }\end{array}$} & Rate of credit provided to technology unit & $\begin{array}{l}\text { Support assistance / } \\
\text { Financial unit }\end{array}$ \\
\hline & & & $\begin{array}{l}\text { Rate of credit provided to units in firm in } \\
\text { festival }\end{array}$ & $\begin{array}{l}\text { Support assistance / } \\
\text { Financial unit }\end{array}$ \\
\hline & & & $\begin{array}{l}\text { Satisfaction rate of technology units from } \\
\text { park }\end{array}$ & $\begin{array}{l}\text { Support assistance / } \\
\text { Industry unit }\end{array}$ \\
\hline & & & $\begin{array}{l}\text { Percent of using equipment by technology } \\
\text { unit }\end{array}$ & $\begin{array}{l}\text { Support assistance / } \\
\text { Supplies unit }\end{array}$ \\
\hline \multirow{3}{*}{4} & \multirow{3}{*}{$\begin{array}{l}\text { Internal } \\
\text { process } \\
\text { Perspective }\end{array}$} & \multirow{3}{*}{$\begin{array}{l}\text { Supporting creation and extension } \\
\text { of technology small and medium } \\
\text { firms and supporting research firms } \\
\text { with technology developing and } \\
\text { employment goal }\end{array}$} & $\begin{array}{l}\text { Rate of using improving process of doing } \\
\text { work }\end{array}$ & $\begin{array}{l}\text { Technology assistance / } \\
\text { Research unit }\end{array}$ \\
\hline & & & $\begin{array}{l}\text { Percent of existence of promotion, and } \\
\text { encouragement in park }\end{array}$ & $\begin{array}{l}\text { Support assistance / } \\
\text { Financial an Industrial unit }\end{array}$ \\
\hline & & & $\begin{array}{l}\text { Rate of using information technology to } \\
\text { doing works of technology units }\end{array}$ & $\begin{array}{l}\text { Support assistance / } \\
\text { Information technology } \\
\text { unit }\end{array}$ \\
\hline
\end{tabular}




\subsection{Establishment and executing}

Different organizations based on the nature of their activities perform various activities depending on their priorities to determine their balanced scorecard values. Park's managers, experts and elites determine these values in Semnan university science and Technology Par using a continuous improvement. In this article based on Fig 3 and using technique of group analytical hierarchy process (AHP), we determined importance and indices values (Wongrassamee et al., 2003).

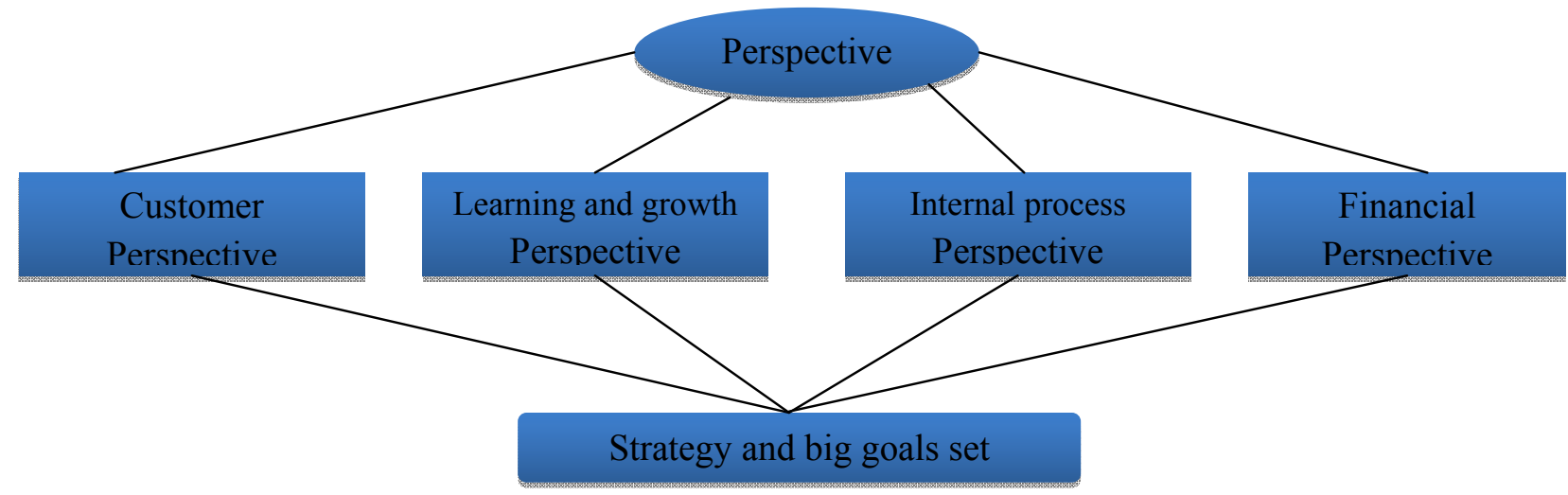

Fig. 3. Hierarchy plane of strategies set (Niazi, 2011)

We have calculated different weights associated with four BSC perspectives and they are summarized in Table 3 and Table 4.

Table 3

Pair comparisons matrix of balanced scorecard perspective in the respective of experts

\begin{tabular}{lllll}
\hline \multirow{2}{*}{ Balanced scorecard perspective } & $\begin{array}{l}\text { Customer } \\
\text { Perspective }\end{array}$ & $\begin{array}{l}\text { Learning and growth } \\
\text { Perspective }\end{array}$ & $\begin{array}{l}\text { Internal process } \\
\text { Perspective }\end{array}$ & $\begin{array}{l}\text { Financial } \\
\text { Perspective }\end{array}$ \\
\hline Financial perspective & 0.38 & 0.35 & 1.55 & 1.00 \\
Internal process perspective & 0.41 & 0.21 & 1.00 & 0.64 \\
Learning and growth perspective & 2.46 & 1.00 & 4.78 & 2.89 \\
Customer perspective & 1.00 & 0.41 & 2.44 & 2.64 \\
\hline Total & 4.25 & 1.97 & 9.77 & 7.17 \\
\hline
\end{tabular}

Table 4

Values of pair comparisons matrix of balanced scorecard perspective in the respective of experts

\begin{tabular}{llllll}
\hline \multirow{2}{*}{ Balanced scorecard perspective } & $\begin{array}{l}\text { Customer } \\
\text { Perspective }\end{array}$ & $\begin{array}{l}\text { Learning and growth } \\
\text { Perspective }\end{array}$ & $\begin{array}{l}\text { Internal process } \\
\text { Perspective }\end{array}$ & $\begin{array}{l}\text { Financial } \\
\text { Perspective }\end{array}$ & Wi \\
\hline Financial perspective & 0.089 & 0.178 & 0.159 & 0.139 & 0.141 \\
Internal process perspective & 0.096 & 0.107 & 0.102 & 0.089 & 0.099 \\
Learning and growth perspective & 0.579 & 0.508 & 0.489 & 0.403 & 0.495 \\
Customer perspective & 0.235 & 0.208 & 0.250 & 0.368 & 0.265 \\
\hline Total & 1 & 1 & 1 & 1 & 1 \\
\hline
\end{tabular}

\subsection{Calculating indices in different perspective}

In Semnan University Technology and Science Park balanced scorecard team from interviewing with experts and elites, competitor information and also with regarding to relation each measurement with other measurement, targeted measurement. As it mentioned, four perspectives and balanced scorecard indices have specific values that are effective in calculations related to different levels. Recent rate of achieving to each index related to ideal value and to total efficiency for each balanced scorecard perspective and Semnan University Technology and Science Park's efficiency received regarding to following calculations.

$X_{i}=F_{i} / T_{i} \quad X_{i}=$ Percent rate of achieving to $I$ index to goal value. 


$$
\mathrm{F}_{\mathrm{i}}=\text { Real rate of I index. } \quad \mathrm{T}_{\mathrm{i}}=\text { Ideal rate of } \mathrm{I} \text { index }
$$

$\mathrm{Y}_{\mathrm{j}}=\sum \mathrm{W}_{\mathrm{ij}} \mathrm{X}_{\mathrm{ij}} \quad \mathrm{Y}_{\mathrm{j}}=$ Efficiency of $\mathrm{J}$ perspective $\quad \mathrm{W}_{\mathrm{ij}}=$ Value of $\mathrm{I}$ perspective in $\mathrm{J}$ perspective

$$
\mathrm{X}_{\mathrm{ij}}=\text { Percent rate of achieving I index in J perspective }
$$

$\mathrm{Z}=\sum \mathrm{W}_{\mathrm{j}} * \mathrm{Y}_{\mathrm{j}} \quad \mathrm{Z}=$ Park's efficiency total

$$
\mathrm{W}_{\mathrm{j}}=\text { Value of } \mathrm{J} \text { perspective } \quad \mathrm{Y}_{\mathrm{j}}=\mathrm{J} \text { perspective's efficiency total }
$$

Table 5 macro goals, performance measurement, indices values, also efficiency score of Semnan University Technology and Science Park in 2010.

Table 5

\begin{tabular}{|c|c|c|c|c|c|c|c|c|}
\hline Row & $\begin{array}{l}\text { Essential } \\
\text { goals in } \\
\text { financial } \\
\text { perspective }\end{array}$ & $\begin{array}{l}\text { Performance } \\
\text { measurement }\end{array}$ & $\begin{array}{l}\mathrm{W}_{\mathrm{ij}} \\
\text { Indices } \\
\text { values }\end{array}$ & $\begin{array}{l}\mathrm{F}_{\mathrm{i}} \\
\text { Existent } \\
\text { values }\end{array}$ & $\begin{array}{l}T_{i} \\
\text { Ideal } \\
\text { values }\end{array}$ & $\begin{array}{l}\mathrm{X}_{\mathrm{i}} \\
\text { Percent Rate } \\
\text { achieving to } \\
\text { goal }\end{array}$ & $\begin{array}{l}\mathrm{W}_{\mathrm{ij}} * \mathrm{X}_{\mathrm{i}} \\
\text { Efficiency } \\
\text { of each } \\
\text { index }\end{array}$ & $\begin{array}{l}\mathrm{Y}_{\mathrm{i}}=\sum \mathrm{W}_{\mathrm{ij}} * \mathrm{X}_{\mathrm{i}} \\
\text { Efficiency of } \\
\text { total } \\
\text { perspective }\end{array}$ \\
\hline 1 & \multirow{3}{*}{$\begin{array}{l}\text { Make trading } \\
\text { ideas and } \\
\text { applying } \\
\text { university } \\
\text { research } \\
\text { results }\end{array}$} & $\begin{array}{l}\text { Percent rate of } \\
\text { financial } \\
\text { support from } \\
\text { fixed planes }\end{array}$ & 0.406 & 2110 & 2268 & $93 \%$ & $37.7 \%$ & \multirow{3}{*}{$95.3 \%$} \\
\hline 2 & & $\begin{array}{l}\text { Rate of spend } \\
\text { budget for long } \\
\text { term } \\
\text { improvement }\end{array}$ & 0.356 & 1596 & 1680 & $95 \%$ & $33.8 \%$ & \\
\hline 3 & & $\begin{array}{l}\text { Rate of budget } \\
\text { spending }\end{array}$ & 0.238 & 252 & 252 & $100 \%$ & $23.8 \%$ & \\
\hline
\end{tabular}

Calculating balanced scorecard indices from financial perspective in Semnan University Technology and Science Park

Internal process perspective plays important role in performance improvement of parks. In other words, they help technology units and provide strategies for keeping, attracting and accepting technology units to park, and in order hand they move along park's financial goals to meet beneficiary's expectations. Table 6 provide macro goals, performance measurement, indices values and also efficient of internal process perspective of Semnan University Technology and Science Park in 2010 .

\section{Table 6}

\begin{tabular}{|c|c|c|c|c|c|c|c|c|}
\hline & \multirow{2}{*}{$\begin{array}{l}\text { Essential goals } \\
\text { in internal } \\
\text { process } \\
\text { perspective }\end{array}$} & \multirow{2}{*}{$\begin{array}{l}\text { Performance } \\
\text { measurement }\end{array}$} & $\overline{W_{i j}}$ & $\overline{F_{i}}$ & $\mathrm{~T}_{\mathrm{i}}$ & $\mathrm{X}_{\mathrm{i}}$ & $\mathrm{W}_{\mathrm{ij}} * \mathrm{X}_{\mathrm{i}}$ & $\mathrm{Y}_{\mathrm{i}}=\sum \mathrm{W}_{\mathrm{ij}} * \mathrm{X}_{\mathrm{i}}$ \\
\hline & & & $\begin{array}{l}\text { Indices } \\
\text { values }\end{array}$ & $\begin{array}{l}\text { Existent } \\
\text { values }\end{array}$ & $\begin{array}{l}\text { Ideal } \\
\text { values }\end{array}$ & $\begin{array}{l}\text { Percent Rate } \\
\text { achieving to } \\
\text { goal }\end{array}$ & $\begin{array}{l}\text { Efficiency } \\
\text { of each } \\
\text { index }\end{array}$ & $\begin{array}{r}\text { Efficiency of } \\
\text { total } \\
\text { perspective }\end{array}$ \\
\hline 1 & $\begin{array}{l}\text { Supporting } \\
\text { creation and } \\
\text { extension of }\end{array}$ & $\begin{array}{l}\text { Rate of using } \\
\text { improving process } \\
\text { of doing work }\end{array}$ & 0.112 & 30 & 43 & $69.7 \%$ & $7.8 \%$ & \\
\hline 2 & $\begin{array}{l}\text { technology } \\
\text { small and } \\
\text { medium firms } \\
\text { and supporting } \\
\text { research firms }\end{array}$ & $\begin{array}{l}\text { Percent of } \\
\text { existence of } \\
\text { promotion, and } \\
\text { encouragement in } \\
\text { park }\end{array}$ & 0.694 & 78 & 100 & $78 \%$ & $54.1 \%$ & $80.5 \%$ \\
\hline 3 & $\begin{array}{l}\text { with } \\
\text { technology } \\
\text { developing } \\
\text { and } \\
\text { employment } \\
\text { goal }\end{array}$ & $\begin{array}{l}\text { Rate of using } \\
\text { information } \\
\text { technology to } \\
\text { doing works of } \\
\text { technology units }\end{array}$ & 0.194 & 55 & 60 & $91.6 \%$ & $18.6 \%$ & \\
\hline
\end{tabular}

Calculating balanced scorecard indices from internal process perspective in Semnan University Technology and Science Park 
Today commission of all firms is focuses on customers: "Best and first commission in providing value to customer". Customer perspective indicate park's strategy and process for providing service to technology unit and reflect what is important for units that really is value chain for technology units. Table 7 provides macro goal, performance measurement, indices values and efficiency score of Semnan University Technology and Science Park in 2010.

Table 7

Calculating balanced scorecard indices from customer perspective in Semnan University Technology and Science Park

\begin{tabular}{|c|c|c|c|c|c|c|c|c|}
\hline & \multirow{2}{*}{$\begin{array}{r}\text { Essential goals in } \\
\text { customer } \\
\text { perspective }\end{array}$} & \multirow{2}{*}{$\begin{array}{l}\text { Performance } \\
\text { measurement }\end{array}$} & $\mathrm{W}_{\mathrm{ij}}$ & $\overline{F_{i}}$ & $\mathrm{~T}_{\mathrm{i}}$ & $\overline{X_{i}}$ & $\mathrm{~W}_{\mathrm{ij}} * \mathrm{X}_{\mathrm{i}}$ & $\mathrm{Y}_{\mathrm{i}}=\sum \mathrm{W}_{\mathrm{ij}}{ }^{*} \mathrm{X}_{\mathrm{i}}$ \\
\hline Row & & & $\begin{array}{r}\text { Indices } \\
\text { values }\end{array}$ & $\begin{array}{r}\text { Existent } \\
\text { values }\end{array}$ & $\begin{array}{r}\text { Ideal } \\
\text { values }\end{array}$ & $\begin{array}{r}\text { Percent Rate } \\
\text { achieving to goal }\end{array}$ & $\begin{array}{r}\text { Efficiency of } \\
\text { each index }\end{array}$ & $\begin{array}{r}\text { Efficiency of } \\
\text { total } \\
\text { perspective }\end{array}$ \\
\hline 1 & \multirow{4}{*}{$\begin{array}{l}\text { Using public and } \\
\text { university } \\
\text { equipment for } \\
\text { services, } \\
\text { supporting, } \\
\text { initiative and } \\
\text { extending } \\
\text { technology in } \\
\text { society }\end{array}$} & $\begin{array}{r}\text { Rate of credit provided } \\
\text { to technology unit }\end{array}$ & 0.671 & 3048 & 3810 & $80 \%$ & $53.6 \%$ & \multirow{4}{*}{$80.5 \%$} \\
\hline 2 & & $\begin{array}{r}\text { Rate of credit provided } \\
\text { to units in firm in } \\
\text { festival }\end{array}$ & 0.069 & 350 & 430 & $81 \%$ & $5.5 \%$ & \\
\hline 3 & & $\begin{array}{r}\text { Satisfaction rate of } \\
\text { technology units from } \\
\text { park }\end{array}$ & 0.126 & 85 & 100 & $85 \%$ & $10.7 \%$ & \\
\hline 4 & & $\begin{array}{r}\text { Percent of using } \\
\text { equipment by } \\
\text { technology unit }\end{array}$ & 0.134 & 40 & 50 & $80 \%$ & $10.7 \%$ & \\
\hline
\end{tabular}

Learning and growth perspective identify necessary substructure for long-term growth and park's duration. This perspective with strengthening park's principle resources, which includes people, system and trends can decrease existing gap in park between capabilities and capacities. Table 8 provides macro goals, performance measurement, indices values also efficiency of learning and growth perspective of Semnan University Technology and Science Park in 2010.

\section{Table 8}

Calculating balanced scorecard indices from learning and growth perspective in Semnan University Technology and Science Park

\begin{tabular}{|c|c|c|c|c|c|c|c|c|c|}
\hline Row & $\begin{array}{l}\text { Essential goals } \\
\text { in learning and } \\
\text { growth } \\
\text { perspective }\end{array}$ & $\begin{array}{l}\text { Performance } \\
\text { measurement }\end{array}$ & $\begin{array}{l}\mathrm{W}_{\mathrm{ij}} \\
\text { Goals } \\
\text { values }\end{array}$ & $\begin{array}{l}\mathrm{W}_{\mathrm{ij}} \\
\text { Indices } \\
\text { values }\end{array}$ & $\begin{array}{l}\mathrm{F}_{\mathrm{i}} \\
\text { Existent } \\
\text { values }\end{array}$ & $\begin{array}{l}T_{i} \\
\text { Ideal } \\
\text { values }\end{array}$ & $\begin{array}{l}X_{i} \\
\text { Percent } \\
\text { Rate } \\
\text { achieving to } \\
\text { goal }\end{array}$ & $\begin{array}{l}W_{i j} * X_{i} \\
\text { Efficiency of each } \\
\text { index }\end{array}$ & $\begin{array}{r}\mathrm{Y}_{\mathrm{i}}=\sum \mathrm{W}_{\mathrm{ij}} * \mathrm{X}_{\mathrm{i}} \\
\text { Efficiency of } \\
\text { total } \\
\text { perspective }\end{array}$ \\
\hline 1 & \multirow{4}{*}{ 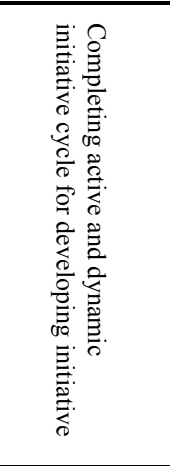 } & $\begin{array}{l}\text { Efficiency rate } \\
\text { of park's } \\
\text { supporting from } \\
\text { technology units }\end{array}$ & \multirow{4}{*}{0.541} & 0.514 & 50 & 57 & $87.7 \%$ & $45 \%$ & \multirow{5}{*}{$75.6 \%$} \\
\hline 2 & & $\begin{array}{l}\text { Number of } \\
\text { technology unit } \\
\text { to develop }\end{array}$ & & 0.327 & 43 & 50 & $86 \%$ & $28.1 \%$ & \\
\hline 3 & & $\begin{array}{l}\text { Percent of } \\
\text { growth of } \\
\text { technology units } \\
\text { from scientist } \\
\text { environment }\end{array}$ & & 0.088 & 30 & 45 & $66.6 \%$ & $45.8 \%$ & \\
\hline 4 & & $\begin{array}{l}\text { Hold educational } \\
\text { hours for } \\
\text { technology units }\end{array}$ & & 0.071 & 142 & 171 & $83 \%$ & $5.8 \%$ & \\
\hline 5 & 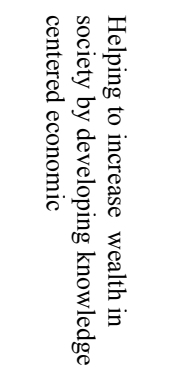 & $\begin{array}{l}\text { Number of } \\
\text { provided ideas in } \\
\text { market }\end{array}$ & 0.459 & 1 & 28 & 43 & $65.1 \%$ & $29.8 \%$ & \\
\hline
\end{tabular}




\section{4 calculating Park's total efficiency index}

With calculating park's total efficiency index, park's performance in four perspectives of learning and growth, internal process, customers and financial have been measured that can show these calculations in table 9. With inserting above cases in performance evaluation system, one can expect that this system cause to increasing stimulation staff, managers and technology units and therefore improving Semnan University Technology and Science Park.

\section{Table 9}

Total efficiency of Semnan University Technology and Science Park

\begin{tabular}{|c|c|c|c|c|c|}
\hline & & $\mathrm{W}_{\mathrm{ij}}$ & $\overline{Y_{j}}$ & $\mathrm{~W}_{\mathrm{ij}} * \mathrm{Y}_{\mathrm{j}}$ & $\overline{Z_{j}}=\sum W_{i j} * Y_{j}$ \\
\hline Row & Balanced Scorecard Perspective & $\begin{array}{l}\text { Perspective } \\
\text { values }\end{array}$ & Total efficiency & $\begin{array}{l}\text { Efficiency in } \\
\text { each perspective }\end{array}$ & Total efficiency \\
\hline 1 & Financial Perspective & 0.141 & $95.3 \%$ & $13.4 \%$ & \multirow{4}{*}{$80 \%$} \\
\hline 2 & Internal Process Perspective & 0.099 & $80.5 \%$ & $7.9 \%$ & \\
\hline 3 & Customer Perspective & 0.265 & $80.5 \%$ & $21.3 \%$ & \\
\hline 4 & Learning and Growth Perspective & 0.495 & $75.6 \%$ & $37.4 \%$ & \\
\hline
\end{tabular}

As we can observe from the results of Table 9, learning and growth perspective" with $37.4 \%$ score has highest score in Semnan University Technology and Science Park, and "internal process perspective" with 7.9\% score has lowest score in Semnan University Technology and Science Park.

\section{Results}

Table 10 shows BSC perspectives, parks strategic, essential macro goals measurement index, final score and efficiently of each perspective. The proposed model of this article indicates that one can evaluate park's performance with total efficiency and it is possible to do corrective actions in activities to determine appropriate measurement indexes, efficiency of Technology and Science Park of Semnan University.

As we can see from the results of Table 10, total efficiency of financial perspective was $13.4 \%$. Therefore, we can say that this perspective in Technology and Science Park has acceptable score, since there were some limitations on budgets.

Learning and growth perspective efficiency was 37.4\%. Since Semnan University Technology and Science Park's growth and learning perspective has been made out of two essential goals and five indices, one can say that this perspective in Technology and Science Park has relatively good performance. In addition, the same arguments hold for customer perspective, which maintains a total efficiency of $21.3 \%$.

Customer perspective includes some public measurement such as customer satisfaction, customer keeping, customer attracting, customer profitability, customer loyalty, market share, etc. Finally Semnan Technology and Science Park's internal process perspective was $7.9 \%$. Since Semnan University Technology and Science Park's internal process perspective has been made from one essential goal and three indices, one can say that this perspective in Technology and Science Park has lowest score. The reason for having low performance was that the unit was recently established Park. Thus, the programs for receiving these goals and determinants must be prepared by Park's managements. 
Table 10

Perspective efficiency, goals and indices in Semnan University Technology and Science Park

\begin{tabular}{|c|c|c|c|c|c|c|c|}
\hline Row & $\begin{array}{l}\text { Perspectives of } \\
\text { balanced } \\
\text { scorecard }\end{array}$ & $\begin{array}{l}\text { Efficiency of } \\
\text { each } \\
\text { Perspective }\end{array}$ & Essential macro goals & $\begin{array}{l}\text { Efficiency of } \\
\text { each goal }\end{array}$ & $\begin{array}{l}\text { Index (performance } \\
\text { measurement) }\end{array}$ & $\begin{array}{l}\text { Efficiency of } \\
\text { each index }\end{array}$ & $\begin{array}{l}\text { Total } \\
\text { efficiency }\end{array}$ \\
\hline \multirow{3}{*}{1} & \multirow{3}{*}{$\begin{array}{c}\text { Financial } \\
\text { Perspective }\end{array}$} & \multirow{3}{*}{$13.4 \%$} & \multirow{3}{*}{$\begin{array}{l}\text { Make trading ideas } \\
\text { and applicability } \\
\text { university research } \\
\text { results }\end{array}$} & \multirow{3}{*}{$95.3 \%$} & $\begin{array}{l}\text { Percent rate of financial } \\
\text { support from fixed } \\
\text { planes }\end{array}$ & $37.7 \%$ & \multirow{15}{*}{$80 \%$} \\
\hline & & & & & $\begin{array}{l}\text { Rate of spend budget in } \\
\text { along improving and } \\
\text { extending park }\end{array}$ & $33.8 \%$ & \\
\hline & & & & & $\begin{array}{l}\text { Rate of spend budget in } \\
\text { doing research }\end{array}$ & $23.8 \%$ & \\
\hline \multirow{5}{*}{2} & \multirow{5}{*}{$\begin{array}{l}\text { Learning and } \\
\text { Growth } \\
\text { Perspective }\end{array}$} & \multirow{5}{*}{$37.4 \%$} & \multirow{4}{*}{$\begin{array}{l}\text { Completing active } \\
\text { and dynamic cycle } \\
\text { for developing } \\
\text { initiative }\end{array}$} & \multirow{4}{*}{$45.8 \%$} & $\begin{array}{l}\text { Efficiency rate of park's } \\
\text { supporting from } \\
\text { technology units }\end{array}$ & $45 \%$ & \\
\hline & & & & & $\begin{array}{l}\text { Number of technology } \\
\text { unit to develop }\end{array}$ & $28.1 \%$ & \\
\hline & & & & & $\begin{array}{l}\text { Percent of growth of } \\
\text { technology units from } \\
\text { scientist environment }\end{array}$ & $5.8 \%$ & \\
\hline & & & & & $\begin{array}{l}\text { Hold educational hours } \\
\text { for technology units }\end{array}$ & $5.8 \%$ & \\
\hline & & & $\begin{array}{l}\text { Helping to increasing } \\
\text { wealth in society by } \\
\text { developing } \\
\text { knowledge centered } \\
\text { economic }\end{array}$ & $29.8 \%$ & $\begin{array}{l}\text { Number of provided } \\
\text { ideas in market }\end{array}$ & $29.8 \%$ & \\
\hline \multirow{4}{*}{3} & \multirow{4}{*}{$\begin{array}{l}\text { Customer } \\
\text { Perspective }\end{array}$} & \multirow{4}{*}{$21.3 \%$} & \multirow{4}{*}{$\begin{array}{l}\text { Using public and } \\
\text { university equipment } \\
\text { for services, } \\
\text { supporting, initiative } \\
\text { and extending } \\
\text { technology in society }\end{array}$} & \multirow{4}{*}{$80.5 \%$} & $\begin{array}{l}\text { Rate of credit provided } \\
\text { to technology unit }\end{array}$ & $53.6 \%$ & \\
\hline & & & & & $\begin{array}{l}\text { Rate of credit provided } \\
\text { to units in firm in festival }\end{array}$ & $5.5 \%$ & \\
\hline & & & & & $\begin{array}{l}\text { Satistification rate of } \\
\text { technology units from } \\
\text { park }\end{array}$ & $10.7 \%$ & \\
\hline & & & & & $\begin{array}{l}\text { Percent of using } \\
\text { equipment by technology } \\
\text { unit }\end{array}$ & $10.7 \%$ & \\
\hline \multirow{3}{*}{4} & \multirow{3}{*}{$\begin{array}{l}\text { Internal Process } \\
\text { Perspective }\end{array}$} & \multirow{3}{*}{$7.9 \%$} & \multirow{3}{*}{$\begin{array}{l}\text { Supporting creation } \\
\text { and extension of } \\
\text { technology small and } \\
\text { medium firms and } \\
\text { supporting research } \\
\text { firms with } \\
\text { technology } \\
\text { developing and } \\
\text { employment goal }\end{array}$} & \multirow{3}{*}{$80.5 \%$} & $\begin{array}{l}\text { Rate of using improving } \\
\text { process of doing work }\end{array}$ & $7.8 \%$ & \\
\hline & & & & & $\begin{array}{l}\text { Percent of existence of } \\
\text { promotion, and } \\
\text { encouragement in park }\end{array}$ & $54.1 \%$ & \\
\hline & & & & & $\begin{array}{l}\text { Rate of using } \\
\text { information technology } \\
\text { to doing works of } \\
\text { technology units }\end{array}$ & $18.6 \%$ & \\
\hline
\end{tabular}

\section{Conclusion}

We have explained that research parks play essential role in developing economy since they these units could provide new ideas for industries. Industries could implement the ideas developed in pilot plan scales in research parks. In fact, many premature ideas could be first initiated in such units and interested investors or venture capitals could use new ideas to start new businesses, which could end up having some value added firms.

The proposed model of this paper implemented BSC for one of recently established research parks in province of Semnan, Iran. We have made an assessment on four measures of BSC perspectives and determined the present status of these units.

\section{Acknowledgments}

Scholars thank from all of the Park Semnan University workers, especially from presidency Park and technology assistant for their co-workers in the research period. 


\section{References}

Ashley, A., Tiwana, B. A., \& Tsuji, H. (2008). An empirical investigation of the drivers of software outsourcing decisions in Japanese organizations. Information and Software Technology, 50, 499510.

Huang, H.C. (2009). Designing a knowledge-based system for strategic planning: A balanced scorecard perspective. Expert System with Applications, 36(1), 209-218.

Kaplan, R. S. \& Norton, D, P. (2000). Having trouble with your strategy? Then map it. Harvard Business Review, 42-134.

Kaplan, R, S. \& Norton, D, P. (1992). The Balanced Scorecard: Measures That Drive Performance, Harvard Business Review, 71-75.

Kaplan, R, S. \& Norton, D, P. (1996a). Translating Strategy into Action the Balanced Scorecard. Harvard Business School Press, Boston.

Kaplan, R, S. \& Norton, D, P. (2005). The Strategy-Focused organization: How Balanced Scorecard Companies Thrive in New Business Environment. Harvard Business School Press, Boston, MA.

Khan, S. U., \& Niazi, M. \& Ahmad, R. (2011). Factors influencing clients in the selection of offshore software outsourcing. Journal of Systems and Software, 84(4), 686-699.

Kloot, L., \& Martin, J. (2008). Strategic performance management: A balanced approach to performance management issues in local government. Management Accounting Research, 11, 76.

Koskela, E. \& Stenbacka, R. (2009). Equilibrium unemployment with outsourcing under labour market imperfections. Labour Economics 16, 284-290.

Tohidi, H., Jafari, A., \& Azimi Afshar, A. (2010). Using balanced scorecard in educational organizations. Procedia Social and Behavioral Sciences, 2, 5544-5548.

Wu, H.Y., Tzeng, G.H., \& Chen, Y.H. (2009). A fuzzy MCDM approach for evaluating banking performance based on Balanced Scorecard. Expert Systems with Applications, 36, 10135-10147.

Wu, H. Y., Lin, Y.K., \& Chang, C. H. (2011). Performance evaluation of extension education centers in universities based on the balanced scorecard. Expert Systems with Applications,

Oly Ndubisi, N. (2011). Conflict handling, trust and commitment in outsourcing relationship. A Chinese and Indian study, Industrial Marketing Management, 40, 109-117.

Niyon, P, R. (2002). Balanced Scorecard Step-by-Step: Maximizing Performance and Maintaining Results. John Wiley \& Sons, Inc, New York.

Wongrassamee, P, D., Gardiner, J, E. \& Simmons, L. (2003). Performance measurement tools the BSC and the EFQM excellence model. Measuring Business Excellence, 7(1), 14-29. 